\title{
Insects on decomposing carcasses of small rodents in a secondary forest in Southeastern Brazil
}

\author{
Thiago de Carvalho MORETTi ${ }^{1}$, Odair Benedito RiBeiro ${ }^{1}$, Patrícia Jacqueline THYSSEN ${ }^{2}$ \\ and DANIEL RuSS SOLIS ${ }^{3}$
${ }^{1}$ Departamento de Parasitologia, Instituto de Biologia, Universidade Estadual de Campinas, UNICAMP, Campinas, SP, Brazil; e-mail: tcmoretti@yahoo.com.br
${ }^{2}$ Departamento de Parasitologia, Instituto de Biociências, Universidade Estadual Paulista, UNESP, Botucatu, SP, Brazil
${ }^{3}$ Departamento de Biologia, Instituto de Biociências, Universidade Estadual Paulista, UNESP, Rio Claro, SP, Brazil

Key words. Forensic arthropodology, carrion decomposition, Diptera, sarcosaprophagous fauna, Brazil

\begin{abstract}
The decomposition of small carcasses in the open is frequently neglected although it may provide information of forensic importance. This paper describes an experimental study of arthropod species associated with carcasses of mouse, Mus musculus (Linnaeus, 1758) and rat, Rattus norvegicus (Berkenhout, 1769) (Rodentia: Muridae). Four carcasses were left inside iron cages in sunlit and shady areas in a secondary forest in Southeastern Brazil twice a season for four seasons ( $\mathrm{n}=16$ carcasses of each rodent). The carcasses were removed when arthropods ceased to visit them. The visiting and colonizing invertebrates were collected daily and identified. Immatures were also collected and reared in a laboratory for identification. We collected 6,514 arthropods (820 adults and 5,694 juvenile forms) belonging to 53 species from the families Sarcophagidae, Calliphoridae, Muscidae, Fanniidae, Syrphidae, Richardiidae, Sepsidae, Micropezidae, Otitidae, Drosophilidae, Phoridae, Dolichopodidae, Anthomyiidae, Asilidae and Lauxaniidae (Diptera), Formicidae, Ichneumonidae, Encyrtidae and Apidae (Hymenoptera), Staphylinidae (Coleoptera) and Gonyleptidae (Opiliones). Lucilia eximia (Wiedemann, 1819) (Diptera: Calliphoridae) and Peckia (Pattonella) intermutans (Walker, 1861) (Diptera: Sarcophagidae) deserve special attention because both adult and immature forms were collected in all seasons and in both areas. Our results indicate that the frequency of occurrence of these arthropods was positively associated with carcass size (mouse or rat); no marked insect succession on the carcasses occurred; and the diversity of Calliphoridae and Sarcophagidae was high, irrespective of season.
\end{abstract}

\section{INTRODUCTION}

Determining the time of death might be of crucial importance in a forensic investigation. For this, careful analysis of the invertebrates living on/in a carcass may provide useful information. For instance, the type of organism and the developmental stage may be important in estimating how long a carcass has been in a given location. Only rapidly-colonizing species develop on carcasses because physical, chemical and biological conditions in such a microhabitat undergo rapid changes (Hanski, 1987). Although scattered and ephemeral, carrion is highly nutritional and attracts arthropods. However, the species living on/in carcasses immediately after death and the factors acting upon these species are poorly studied.

It is estimated that Diptera and Coleoptera account for $60 \%$ of the fauna associated with decomposing carcasses and, because of that, they are indeed very important in forensic science. For instance, some calliphorid Diptera of the genera Lucilia, Chrysomya, Cochliomyia and Calliphora, and various other genera of Sarcophagidae are abundant and undergo a successional change during decomposition (Bornemissza, 1957; Payne, 1972). However, other orders (Lepidoptera, Hymenoptera, Blattodea, Hemiptera, Isoptera and Dermaptera) and even other arthropods groups such as spiders, harvestmen, centipedes, millipedes, isopods and mites are frequently found associated with decomposing remains, but are usually not included in the cadaveric fauna, possibly because nothing is known of their role in decomposition.

In the present study we collected and identified the adult arthropods visiting and immature arthropods developing in decomposing carcasses of small rodents in different seasons, in sunlit and shady areas, and on rodents of different sizes. We analyzed the relative abundance of the arthropods; distinguished the visiting fauna from the locally-developing species; and determined the pattern of insect succession on the decomposing carcasses.

\section{MATERIAL AND METHODS}

\section{Study area}

The study was conducted in a secondary forest (ca. 3,500 $\left.\mathrm{m}^{2}\right)$ in the city of Campinas, São Paulo State, Brazil $\left(22^{\circ} 49^{\prime} 15^{\prime \prime} \mathrm{S}\right.$, $47^{\circ} 04^{\prime} 08^{\prime \prime} \mathrm{W}$ ), from August 2003 to June 2004. Both native and exotic plants occur in this area, such as Typha sp. (cattail), Prunus sphaerocarpa Michx., 1803 (myrtle-cherry), Psidium guajava L., 1753 (guava tree), Croton zehntneri Pax. \& K. Hoffm., 1923 ("canelinha"), Banisteriopsis caapi (Spruce ex Griseb.) C.V. Morton, 1931 (caapi plant), Persea americana Mill., 1768 (avocado), Prunus domestica L., 1753 (plum tree) and Senna multijuga (Rich.) H.S. Irwin \& Barneby, 1982 ("paucigarra"). The climate is markedly seasonal, consisting of a dry season with mild temperatures (winter; mid-June to August) and a warm rainy season (summer; mid-November to March). The two intermediate seasons, autumn (April-May) and spring (Sep- 
tember-November), are characterized by fluctuations in temperature and rainfall (Souza \& Linhares, 1997).

\section{Study model}

We used 16 carcasses of mice (Mus musculus, Swiss lineage) (Linnaeus, 1758) and 16 of albino rats (Rattus norvegicus, Wistar lineage) (Berkenhout, 1769). The animals were killed by cervical dislocation and weighed (Table 1).

\section{Field and laboratory procedures}

Two carcasses of each species were place in the forest on two occasions in each season, totalling 16 animals of each species and 8 experiments over the 4 seasons (Table 1).

Each experiment was finished when the carcasses were no longer visited by adult arthropods. The carcasses were placed inside white plastic boxes $(15 \times 10 \times 10 \mathrm{~cm})$ and arranged $20 \mathrm{~m}$ apart in either sunlit or shady areas in the forest (a mouse and a rat in both the sunlit and shady areas). A thin metal grid at the bottom of the box allowed water to drain away and prevented the escape of insects and maggots. A 4-cm thick layer of vermiculite was placed between the metal grid and the carcass to absorb rainwater. A square steel cage $(30 \times 30 \times 30 \mathrm{~cm} ; 2 \mathrm{~cm}$ grid), fixed to the ground with four iron hooks, covered the plastic box (Fig. 1). This cage prevented large scavengers (e.g. lizards, dogs and vultures) from reaching the carcass.

The carcasses were observed daily for $30 \mathrm{~min}$ from 10:00 to 14:00 h, the peak time of insect activity on carcasses in South America (Baumgartner \& Greenberg, 1985). We collected the flying insects with a hand net and the crawling arthropods directly from the carcasses with ordinary tweezers. The insects collected were brought to the laboratory, killed by freezing at $-20^{\circ} \mathrm{C}$ and identified. Place and time of collection were recorded. Weather conditions in the field were measured daily during insect collection with a Celsius thermometer (model MM 5202-Incoterm ${ }^{\mathrm{TM}}$ ) and a humidity sensor (model 4463, Stäcker $\& \mathrm{Olms}^{\mathrm{TM}}$ ). Further meteorological data were obtained from CEPAGRI -UNICAMP.

When the carcasses were no longer visited by arthropods, immature specimens (larvae and pupae) were collected from the vermiculite layer and reared under controlled laboratory conditions $\left(25 \pm 1{ }^{\circ} \mathrm{C}, 60 \pm 10 \%\right.$ relative humidity) in glass containers containing a layer of vermiculite and covered with organza. The arthropods were identified at emergence.

\section{Statistical analyses}

Numbers of species collected and their abundance were evaluated by ANOVA (analysis of variance) using homogeneity of the abundance values as the null hypothesis; means were compared using Duncan's multiple range test. ANOVA was also used to compare the number of individuals and numbers of insect families on carcasses that differed in size (mouse or rat), season when exposed (winter, autumn, spring or summer) and exposure to sun (sunlight or shade) (Table 2). We tested for interactions between carcass size $\times$ exposure to sun, carcass size $\times$ season, carcass size $\times$ insect family, season $\times$ exposure to sun, season $\times$ insect family and exposure to sun $\times$ insect family. All the analyses were performed using SAS GLM version 6.12 (SAS Institute Inc., 1988). The significance level was set at $\alpha=$ 0.05 .

\section{Species diversity index}

To determine the diversity and seasonal variation in arthropods, the Simpson-Yule index $(\lambda)$ was used (Ludwig \& Reynolds, 1988). This diversity index was calculated only for the families Calliphoridae and Sarcophagidae because they contain the most abundant species involved in the decomposition process.
TABLE 1. Mean climate (temperature, rainfall and relative humidity \pm SD) and carcass features (weight in $g$ and time taken to decay in parenthesis) in the different seasons.

\begin{tabular}{|c|c|c|c|c|c|}
\hline \multirow{3}{*}{ Phase } & \multicolumn{3}{|c|}{ Climate } & \multicolumn{2}{|c|}{$\begin{array}{l}\text { Carcass weight in } \mathrm{g} \\
\text { (time taken to decay) }\end{array}$} \\
\hline & \multirow{2}{*}{$\begin{array}{l}\text { Temp. } \\
\left({ }^{\circ} \mathrm{C}\right)\end{array}$} & \multirow{2}{*}{$\begin{array}{c}\text { Rainfall } \\
(\mathrm{mm})\end{array}$} & \multirow{2}{*}{$\begin{array}{l}\text { R.H. } \\
(\%)\end{array}$} & \multirow{2}{*}{$\begin{array}{c}\text { mouse } \\
\text { sunlit shady }\end{array}$} & \multirow{2}{*}{$\frac{\text { rat }}{\text { sunlit shady }}$} \\
\hline & & & & & \\
\hline & $\begin{array}{l}21.01 \\
\pm 3.64\end{array}$ & $\begin{array}{c}0.78 \\
\pm 1.56\end{array}$ & $\begin{array}{c}58.82 \\
\pm 13.47\end{array}$ & $\begin{array}{cc}27.23 & 29.45 \\
(17) & (16)\end{array}$ & $\begin{array}{c}206.53164 .50 \\
(13) \quad(14)\end{array}$ \\
\hline & & $\begin{array}{c}1.03 \\
\pm 3.10\end{array}$ & $\begin{array}{l}51.67 \\
\pm 2.52\end{array}$ & $\begin{array}{cc}20.14 & 35.23 \\
(8) & (8)\end{array}$ & $\begin{array}{l}215.80200 .20 \\
(9) \quad(8)\end{array}$ \\
\hline $\begin{array}{l}\text { Spring I } \\
\text { (Oct 2003) }\end{array}$ & & & $\begin{array}{r}48.86 \\
\pm 7.99\end{array}$ & $\begin{array}{cc}42.23 & 45.31 \\
(6) & (7)\end{array}$ & $\begin{array}{l}239.70178 .55 \\
(6) \quad(6)\end{array}$ \\
\hline $\begin{array}{c}\text { Spring II } \\
\text { (Dec 2003) }\end{array}$ & & $\begin{array}{c}6.18 \\
\pm 4.55\end{array}$ & $\begin{array}{c}78.0 \\
\pm 4.90\end{array}$ & $\begin{array}{cc}35.90 & 40.69 \\
(4) & (5)\end{array}$ & $\begin{array}{c}251.75179 .25 \\
(6) \quad(6)\end{array}$ \\
\hline $\begin{array}{c}\text { Summer I } \\
(\text { Feb 2004) }\end{array}$ & $\begin{array}{l}31.25 \\
\pm 2.75\end{array}$ & $\begin{array}{c}2.25 \\
\pm 4.50\end{array}$ & $\begin{array}{r}64.25 \\
\pm 9.64\end{array}$ & $\begin{array}{cc}41.25 & 40.65 \\
(4) & (4)\end{array}$ & $\begin{array}{c}156.11180 .40 \\
(4) \quad(4)\end{array}$ \\
\hline $\begin{array}{l}\text { Summer II } \\
\text { (Mar 2004) }\end{array}$ & $\begin{array}{l}28.33 \\
\pm 2.66\end{array}$ & $\begin{array}{c}3.92 \\
\pm 9.50\end{array}$ & $\begin{array}{l}75.17 \\
\pm 11.14\end{array}$ & $\begin{array}{cc}44.42 & 42.16 \\
(5) & (6)\end{array}$ & $\begin{array}{c}187.52185 .95 \\
(5) \quad(5)\end{array}$ \\
\hline $\begin{array}{c}\text { Autumn I } \\
\text { (Apr 2004) }\end{array}$ & $\begin{array}{l}22.22 \\
\pm 1.92\end{array}$ & $\begin{aligned} & 4.54 \\
\pm & 11.21\end{aligned}$ & $\begin{array}{r}73.33 \\
\pm 8.19\end{array}$ & $\begin{array}{cc}28.26 & 25.63 \\
(8) & (8)\end{array}$ & $\begin{array}{c}183.07166 .10 \\
(9) \quad(9)\end{array}$ \\
\hline $\begin{array}{l}\text { Autumn II } \\
\text { (May 2004) }\end{array}$ & $\begin{array}{r}16.94 \\
\pm 1.81\end{array}$ & 5.28 & $\begin{array}{r}79.69 \\
\pm 6.70\end{array}$ & $\begin{array}{cc}30.74 & 28.05 \\
(14) & (16)\end{array}$ & $\begin{array}{c}167.90184 .29 \\
(8) \quad(13)\end{array}$ \\
\hline
\end{tabular}

\section{RESULTS}

\section{Weather conditions and decaying process}

Mean temperatures, relative humidities and rainfall in each season are shown in Table 1. The period of decay varied in different seasons and for different sizes of carcass. The decay sequence was: initial decay, putrefaction, black putrefaction, fermentation and dry decay (Bornemissza, 1957) (Fig. 1).

During the experiment, a mouse carcass placed in the sunlit area underwent mummification. This carcass was removed after 17 days and there was no trace of maggots.

\section{Insect fauna and statistical analyses}

6,514 arthropods (820 adults and 5,694 immatures) were collected from the 32 carcasses. Even though it was primarily intended to collect only flying insects (e.g. flies, wasps and bees), we collected specimens belonging to 21 families in four orders: Diptera (95.39\%), Hymenoptera (4.28\%), Opiliones $(0.26 \%)$ and Coleoptera (0.06\%) (Table 2).

More adult insects were collected from mouse than rat carcasses $(\mathrm{F}=5.59 ; \mathrm{P}<0.0221)$. More were also collected in spring than in the other seasons $(\mathrm{F}=2.91 ; \mathrm{P}<$ 0.0439). Adult insects were more numerous on carcasses placed in sunlit areas $(\mathrm{F}=8.48 ; \mathrm{P}<0.0054)$ and the most abundant insect family was the Formicidae $(\mathrm{F}=4.58 ; \mathrm{P}<$ $0.0001)$. There is a significant association between the number of insect families and the size of the carcass $(\mathrm{F}=$ 8.82; $\mathrm{P}<0.0001)$. However, there were no interactions between the parameters carcass size and exposure to sun $(\mathrm{F}=0.10 ; \mathrm{P}<0.7565)$, carcass size and season $(\mathrm{F}=0.56$; $\mathrm{P}<0.6404)$, season and exposure to sun $(\mathrm{F}=1.21 ; \mathrm{P}<$ $0.3143)$, season and insect family $(\mathrm{F}=1.15 ; \mathrm{P}<0.3330)$ and exposure to sun and insect family $(\mathrm{F}=0.80 ; \mathrm{P}<$ 
TABLE 2. Insects collected from the 32 carcasses in sunlit (SU) or shady (SH) areas in the four seasons.

\begin{tabular}{|c|c|c|c|c|c|c|c|c|}
\hline \multirow{3}{*}{ Specimens } & \multicolumn{8}{|c|}{ Season } \\
\hline & \multicolumn{2}{|c|}{ Winter } & \multicolumn{2}{|c|}{ Spring } & \multicolumn{2}{|c|}{ Summer } & \multicolumn{2}{|c|}{ Autumn } \\
\hline & SH & SU & SH & SU & SH & SU & SH & SU \\
\hline \multicolumn{9}{|l|}{ ORDER COLEOPTERA } \\
\hline \multicolumn{9}{|l|}{ Staphylinidae $(\mathrm{n}=04)(\mathrm{C})$} \\
\hline Eulissus chalybaeus* & & & & 04 & & & & \\
\hline ORDER DIPTERA & & & & & & & & \\
\hline Anthomyiidae $(\mathrm{n}=01)^{*}(\mathrm{C})$ & & & & & & & & 01 \\
\hline Asilidae $(\mathrm{n}=01) *(\mathrm{C})$ & & & & & 01 & & & \\
\hline Calliphoridae $(\mathrm{n}=5,284)(\mathrm{B}, \mathrm{C})$ & & & & & & & & \\
\hline Chrysomya albiceps (Wiedemann, 1819) & 13 & 14 & 12 & 83 & 01 & 77 & & 02 \\
\hline Chrysomya megacephala (Fabricius, 1794)* & 09 & 11 & 04 & 32 & 02 & & & \\
\hline Lucilia eximia (Wiedemann, 1819) & 297 & 13 & 1,234 & 1,257 & 198 & 1,341 & 22 & 17 \\
\hline Hemilucilia segmentaria (Fabricius, 1805) & 02 & & 16 & 01 & 18 & & 404 & 203 \\
\hline Cochliomyia macellaria (Fabricius, 1775)* & & & & 01 & & & & \\
\hline Dolichopodidae $(\mathrm{n}=14) *(\mathrm{C})$ & & & 01 & & 02 & 01 & 09 & 01 \\
\hline Drosophilidae $(\mathrm{n}=25)(\mathrm{B}, \mathrm{C})$ & & & & & & & & \\
\hline Drosophila sp.* & & & & & & & 09 & 16 \\
\hline Fanniidae $(n=258)(C)$ & & & & & & & & \\
\hline Fannia sp. & 10 & & 102 & 35 & 63 & 42 & & 06 \\
\hline Lauxaniidae $(\mathrm{n}=01) *(\mathrm{C})$ & & & & & & & & 01 \\
\hline Micropezidae $(\mathrm{n}=16) *(\mathrm{C})$ & 03 & 01 & 09 & 01 & 01 & & 01 & \\
\hline Muscidae $(n=22)(C)$ & & & & & & & & \\
\hline Musca domestica (Linnaeus, 1758)* & & & & 01 & & & & \\
\hline Sarcopromusca pruna (Shannon \& Del Ponte, 1926)** & & & 20 & & & & & \\
\hline Ophyra solitaria (Albuquerque, 1958)* & & & & & 01 & & & \\
\hline Otitidae $(n=122)(B, A)$ & & & & & & & & \\
\hline Euxesta sp.* & 01 & & & & & 84 & 01 & 36 \\
\hline Phoridae $(\mathrm{n}=03)(\mathrm{C})$ & & & & & & & & \\
\hline Megaselia scalaris (Loew, 1866) & & & & 01 & & & 02 & \\
\hline Richardiidae $(\mathrm{n}=02) *(\mathrm{C})$ & 01 & & & & 01 & & & \\
\hline Sarcophagidae $(n=380)(C)$ & & & & & & & & \\
\hline Peckia (Squamatodes) ingens (Walker, 1849) & & 16 & 03 & 01 & & & & \\
\hline Titanogrypa (Cucullomyia) larvicida (Lopes, 1935)* & & & & & & & & 01 \\
\hline Peckia (Euboettcheria) anguilla (Curran \& Walley, 1934)* & & & & & & & & 01 \\
\hline Peckia (Euboettcheria) collusor (Curran \& Walley, 1934)** & & 05 & & & & & & \\
\hline Helicobia pilifera Lopes, 1939* & & 01 & & & & & & \\
\hline Helicobia pilipleura Lopes, 1939* & 01 & & & & & & 01 & 06 \\
\hline Sarcophaga (Lipoptilocnema) crispina Lopes, 1938* & & & & & & & & 02 \\
\hline Sarcophaga (Lipoptilocnema) crispula Lopes, 1938* & 01 & 01 & & & & & & \\
\hline Oxysarcodexia angrensis Lopes, 1933* & & 01 & & & 02 & & 01 & \\
\hline Oxysarcodexia carvalhoi Lopes, 1946 & & & 04 & & 02 & & 06 & \\
\hline Oxysarcodexia riograndensis Lopes, $1946^{*}$ & & 03 & & & & & & \\
\hline Oxysarcodexia thornax (Walker, 1849)* & 02 & 02 & & & 03 & & & \\
\hline Parasarcophaga sp.* & & & & & & 01 & & \\
\hline Peckia (Pattonella) intermutans (Walker, 1861) & 37 & 03 & 08 & 02 & 17 & 03 & 39 & 12 \\
\hline Peckia (Peckia) chrysostoma (Wiedemann, 1830) & 02 & 02 & 02 & 02 & 01 & & & \\
\hline Peckia (Peckia) pexata (Wulp, 1895)* & & & & 01 & & & & 01 \\
\hline Ravinia belforti (Prado \& Fonseca 1932)* & & & & & 02 & & & 01 \\
\hline Sarcodexia lambens (Wiedemann, 1830)* & 04 & 09 & & 03 & 01 & & & 05 \\
\hline Sarcophaga (Liopygia) ruficornis (Fabricius, 1794) & & 146 & 02 & & & & 01 & \\
\hline Sarcophagula $\mathrm{sp}$. & & 02 & & & & 05 & & \\
\hline Microcerella halli (Engel, 1931)* & & 01 & & & & & & \\
\hline Sepsidae $(\mathrm{n}=09)^{*}(\mathrm{C})$ & 01 & & & & 01 & 06 & & 01 \\
\hline Syrphidae $(\mathrm{n}=75)(\mathrm{B}, \mathrm{C})$ & & & & & & & & \\
\hline Ornidia obesa (Fabricius, 1775)* & & 01 & 03 & 36 & & 03 & & \\
\hline Copestylum sp.* & & & & & & & 01 & \\
\hline Allograpta obliqua (Say, 1823)* & & & & 30 & & & & \\
\hline Baccha sp.* & & & & 01 & & & & \\
\hline ORDER HYMENOPTERA & & & & & & & & \\
\hline Encyrtidae $(n=67)$ & & & & & & & & \\
\hline Tachinaephagus zealandicus (Ashmead, 1904)** & & & & 67 & & & & \\
\hline Ichneumonidae $(\mathrm{n}=04)^{*}(\mathrm{C})$ & & & & 01 & & & 02 & 01 \\
\hline Formicidae $(\mathrm{n}=179)(\mathrm{A})$ & & & & & & & & \\
\hline Cephalotes clypeatus (Fabricius, 1804)* & & & & 82 & & & & \\
\hline Camponotus sp.* & & & & 04 & & & & \\
\hline Atta sexdens (Linnaeus, 1758)* & & & & 02 & & & & 41 \\
\hline Camponotus abdominalis (Fabricius, 1804)* & & & & & & & & 50 \\
\hline Apidae $(\mathrm{n}=29)(\mathrm{B}, \mathrm{A})$ & & & & & & & & \\
\hline Tetragonisca angustula (Latreille, 1811)* & & & & & & & & 29 \\
\hline ORDER OPILIONES & & & & & & & & \\
\hline Gonyleptidae $(\mathrm{n}=17)(\mathrm{B}, \mathrm{A}, \mathrm{C})$ & & & & & & & & \\
\hline Mischonyx cuspidatus (Roewer, 1913)* & 17 & & & & & & & \\
\hline
\end{tabular}



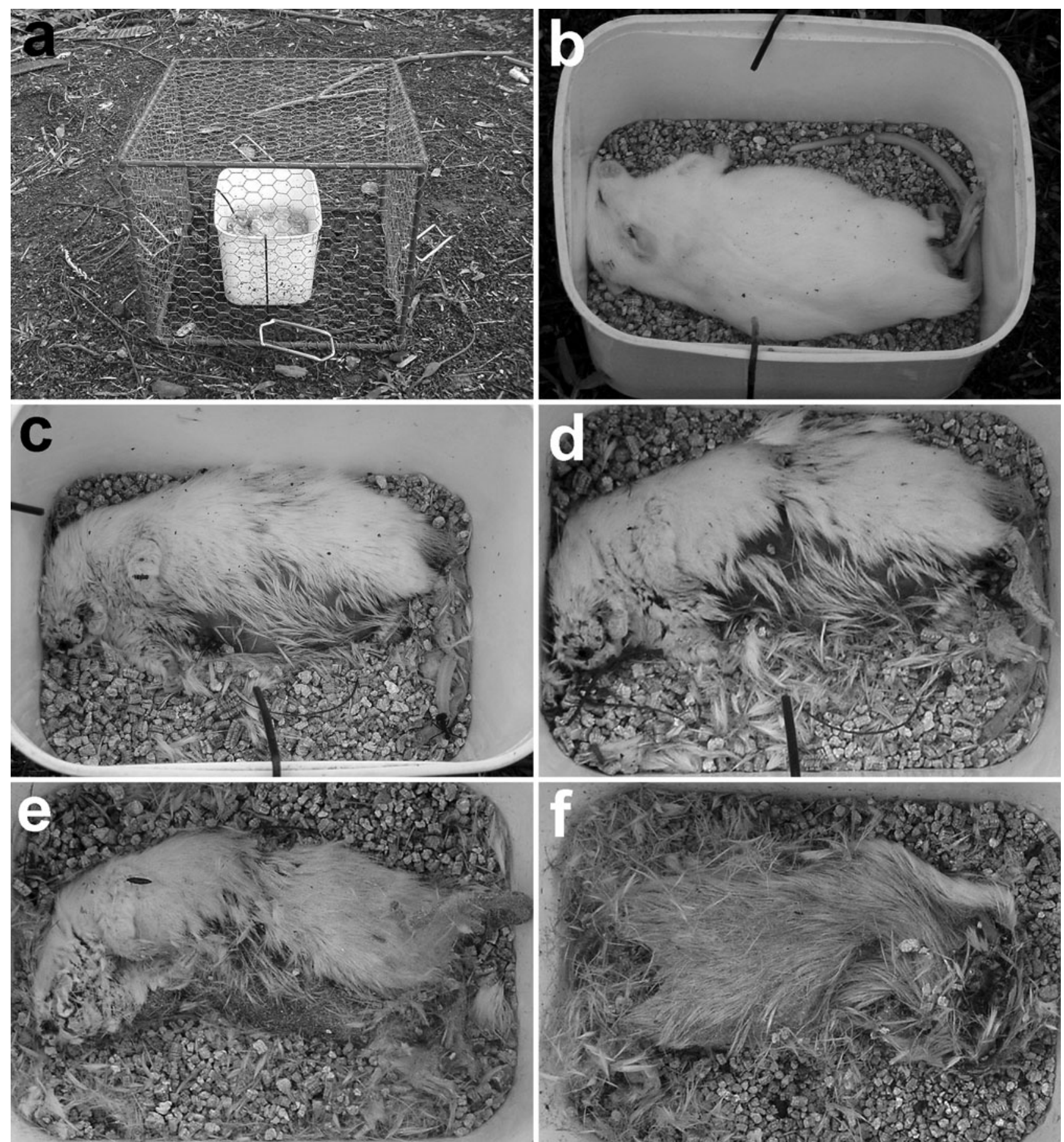

Fig. 1. Experimental cage (a) and decomposition stages of a rat carcass over the course of the experiment: (b) initial decay, (c) putrefaction, (d) black putrefaction, (e) fermentation and (f) dry decay.

0.5715), having as response variable the abundance of insects.

Regarding the immature forms, five families of Diptera were collected, all which utilize carrion for breeding: Calliphoridae (89.25\%), Sarcophagidae (4.98\%), Fanniidae (4.21\%), Muscidae $(0.35 \%)$ and Phoridae $(0.01 \%)$. Insects of the species Tachinaephagus zealandicus (Ashmead, 1904) (1.17\%) (Hymenoptera: Encyrtidae) were found parasitizing the pupae of Chrysomya megacephala (Fabricius, 1794) (Diptera: Calliphoridae) and completed their development in the laboratory.
The number of immature specimens was higher in rat than in mouse carcasses $(\mathrm{F}=9.45 ; \mathrm{P}<0.0106)$. No significant difference in the abundance of immatures was found among the seasons ( $\mathrm{F}=0.57 ; \mathrm{P}<0.6439)$, in the two exposure treatments $(\mathrm{F}=0.00 ; \mathrm{P}<0.9912)$ and among insect families $(\mathrm{F}=1.64 ; \mathrm{P}<0.2292)$. The same was observed for the interactions between carcass size and exposure to sunlight $(\mathrm{F}=0.17 ; \mathrm{P}<0.6862)$, carcass size and season $(\mathrm{F}=0.22 ; \mathrm{P}<0.8784)$, season and exposure to sunlight $(\mathrm{F}=0.65 ; \mathrm{P}<0.5981)$, season and insect family ( $\mathrm{F}=0.47 ; \mathrm{P}<0.7926)$ and exposure to sunlight and insect family $(\mathrm{F}=0.33 ; \mathrm{P}<0.7202)$. 
TABLE 3. Simpson-Yule $(\lambda)$ diversity index for adult flies of the families Calliphoridae and Sarcophagidae collected from either rat or mouse carcasses, in the four seasons.

\begin{tabular}{lcccc}
\hline \multirow{2}{*}{ Season } & \multicolumn{2}{c}{ Rat } & \multicolumn{2}{c}{ Mouse } \\
\cline { 2 - 5 } & $\begin{array}{c}\text { Sarco- } \\
\text { phagidae }\end{array}$ & $\begin{array}{c}\text { Calli- } \\
\text { phoridae }\end{array}$ & $\begin{array}{c}\text { Sarco- } \\
\text { phagidae }\end{array}$ & $\begin{array}{c}\text { Calli- } \\
\text { phoridae }\end{array}$ \\
\hline Winter & 0.24 & 0.36 & 0.02 & NC \\
Spring & NC & 0.50 & 0.24 & 0.38 \\
Summer & 0.66 & 0.40 & 0.11 & $\mathrm{NC}$ \\
Autumn & 0.14 & 0.64 & 0.66 & $\mathrm{NC}$ \\
\hline
\end{tabular}

$\mathrm{NC}=$ not calculated

\section{Diversity index}

The diversity of both Calliphoridae and Sarcophagidae was high for rat carcasses, as indicated by the SimpsonYule index $(\lambda)$, which was below 0.50 in most cases, except for calliphorids in autumn and spring and sarcophagids in summer. For mouse carcasses, $\lambda$ was mostly below 0.50 except for sarcophagids in autumn ( Table 3 ).

\section{DISCUSSION}

The calliphorid L. eximia and the sarcophagid Peckia (Pattonella) intermutans were the only species for which both adult and immature forms were found in all seasons and in both areas. Our results indicate that $L$. eximia is especially adapted for colonizing small carcasses. This strategy possibly avoids competition for food with other necrophagous diptera that colonize carcasses of bigger animals. Another important and unexpected finding was the juvenile forms of $S$. pruna, which is not recorded as necrophagous. Therefore, this species can now be considered to be of potential forensic interest.

The number of Sarcophagidae species collected $(\mathrm{n}=$ $21)$ and that developed in the carcasses $(n=7)$ (Table 2$)$ increases the list of species of potential forensic utility in the Neotropical region and is substantial compared to that recorded in other studies carried out in Brazil - Carvalho et al. (2000) (collected: $\mathrm{n}=1$; developed: $\mathrm{n}=1$ ), Carvalho \& Linhares (2001) (collected: $n=21$; developed: $n$ $=1$ ), Oliveira-Costa et al. (2001) (collected: $n=9$; developed: $n=3$ ), Monteiro-Filho \& Penereiro (1987) (collected $\mathrm{n}=10$; developed: not recorded) and Souza \& Linhares (1997) (collected: $n=17$; developed: $n=3$ ). There are three possible explanations for this. First, difficulties in precisely identifying the species of this family may lead to the inclusion of similar specimens in the same species. Second, the studies were carried out in different areas, such as the state of Rio de Janeiro (OliveiraCosta et al., 2001), which have particular seasonal and/or environmental features. Finally, different carcasses were used: pig carrion was utilized by Carvalho et al. (2000), Carvalho \& Linhares (2001) and Souza \& Linhares (1997), while albino rats (Rattus rattus) and human corpses found in crime scenes were used by MonteiroFilho \& Penereiro (1987) and Oliveira-Costa et al. (2001), respectively.

We assembled a number of species in three distinct groups of arthropods, which we consider unusual: dip- teran species not traditionally included in forensic studies (e.g. Syrphidae and Otitidae) (G1); insects from the order Hymenoptera $(\mathrm{G} 2)$ and arthropods other than insects (G3). In G1, the presence of Allograpta obliqua (Say, 1823) (Diptera: Syrphidae) was particularly remarkable; its larvae usually feed on aphids that are agricultural pests. However, according to Bugg \& Ditcher (1989), in the absence of aphids these larvae may feed on pollen or other food sources in order to complete their development. This syrphid larva may feed on carcasses, which contain a high protein content. However, the possibility that the white plastic boxes attracted the hoverflies must be considered (Laubertie et al., 2006). Also in G1, the saprophagous flies of the genus Euxesta were the most abundant adults in the summer. This genus is generally found on decaying vegetable matter and caterpillar faeces (Link et al., 1984). In G2, the presence of Tetragonisca angustula on animal carcasses may be related to mineral or higher humidity needs rather than to their protein requirement. They could be also attracted to fungi that grow on carcasses during the dark decay stage (Bornemissza, 1957). In fact, some mineral and protein-rich fungi that grow in microhabitats used by stingless bees play an important role in $T$. angustula nutrition (Gilliam et al., 1988). The record of Mischonyx cuspidatus (Roewer, 1913) (Opiliones: Gonyleptidae) specimens in G3 was remarkable since Opiliones are rarely referred to in forensic science. Nevertheless, a more detailed investigation of the feeding habits of this species is necessary to clarify whether it benefits from the carcass or is a predator of the visiting fauna. Moreover, if we had used pitfall traps of the type designed by Kočárek (2000), it is likely we would have collected more specimens of harvestmen, beetles and other crawling arthropods (e.g. cockroaches, spiders, scorpions).

A large number of Diptera were collected from the carcasses in spring and summer. This is likely a seasonal effect, since high temperatures and humidities shorten insect development time and accelerate decomposition, which attracts more flies for oviposition or larviposition. Similar results are recorded by Monteiro-Filho \& Penereiro (1987), who studied decomposition of albino rats in a disturbed primary forest, also in the city of Campinas.

The present study did not find clear evidence of insect succession in the carcasses. However, other studies dealing with small carcasses (e.g. Bornemissza, 1957; Cornaby, 1974; Monteiro-Filho \& Penereiro, 1987) describe colonization as a uniquely patterned process, which can be invaluable in forensic investigations. There was no clear association between decomposition stage $\mathrm{x}$ insect fauna. Moreover, no "colonization waves" were recorded, i.e., flies being abundant during the initial decomposition stages followed by predacious Hymenoptera (e.g. ants) and, in the advanced stages, Coleoptera. We observed a simultaneous arrival of flies (from various families), ants and beetles on the carcasses, as also recorded by Moura et al. (2005). Because small carcasses are a short-lasting resource, the insects may have been 
colonizing simultaneously and establishing themselves in a competitive interaction. Further studies are needed in which the adults and immatures are carefully sampled and more accurately identified, using the decay stages for temporal delimitation (Moura et al., 2005).

The diversity indices obtained for Calliphoridae and Sarcophagidae flies confirmed that there is a high diversity of species throughout the year. Carvalho \& Linhares (2001), however, found a higher diversity of arthropods on pig carcasses during winter, possibly because carcasses take longer to decay at lower temperatures and relative humidities, thus permitting the arrival of a wider array of arthropods. Nonetheless, we should consider the probable existence of different strategies for dealing with carcasses of different sizes, which potentially explains the different diversity indices.

The dimensions of the carcasses (rat/mouse) affected the frequency of adult and immature insects. This finding disagrees with Norris (1965), who reported that this parameter is only different for carcasses that differ greatly in size. He also asserted that carcass dimension is relevant only in slightly-disturbed environments. However, we found carcass size to be an important parameter although the study area is located in the midst of an urbanized portion of Campinas, disturbed by human activities.

ACKNOWLEDGEMENTS. The authors thank Â. Pires do Prado for identifying the acalyptrate families, A.X. Linhares for helping with the statistical analyses, P.S. Oliveira for identifying the ant species, G. Machado for identifying the harvestmen, and C. Antunes de Mello-Patiu for identifying the Sarcophagidae. Critical comments provided by M. Konvička improved the manuscript. Part of the work reported in this paper was submitted by T.C.M. in a dissertation to the State University of Campinas for a Master's degree in Parasitology.

\section{REFERENCES}

Baumgartner D.L. \& Greenberg B. 1985: Distribution and medical ecology of the blow flies (Diptera: Calliphoridae) of Peru. Ann. Entomol. Soc. Am. 78: 565-587.

BoRNEMISSZA G.F. 1957: An analysis of arthropod succession in carrion and the effect of its decomposition on the soil fauna. Aust. J. Zool. 5: 1-12.

BugG R.L. \& Ditcher J.D. 1989: Warm-season cover crops for pecan orchards: horticultural and entomological implications. Biol. Agric. Hortic. 6: 123-148.
Carvalho L.M.L., Thyssen P.J., Linhares A.X. \& Palhares F.B. 2000: A checklist of arthropods associated with carrion and human corpses in southeastern Brazil. Mem. I. Oswaldo Cruz 95: 135-138.

Carvalho L.M.L. \& Linhares A.X. 2001: Seasonality of insect succession and pig carcass decomposition in a natural forest area in southeastern Brazil. J. Forensic Sci. 46: 604-608.

Cornaby B.W. 1974: Carrion reduction by animals in contrasting tropical habitats. Biotropica 6: 51-63.

Gilliam M., Lorenz B.J. \& Richardson G.V. 1988: Digestive enzymes and micro-organisms in honey bees, Apis mellifera: influence of streptomycin, age, season, and pollen. Microbios 55: $95-114$.

HANSKI I. 1987: Carrion fly community dynamics: patchiness, seasonality and coexistence. Ecol. Entomol. 12: 257-266.

KoČÁReK P. 2000: A pitfall trap for carrion ecology studies. Biologia 55: 575-577.

Laubertie E.A., Wratten S.D. \& Sedcole J.R. 2006: The role of odour and visual cues in the pan-trap catching of hoverflies (Diptera: Syrphidae). Ann. Appl. Biol. 148: 173-178.

Link D., Storck L., Cervi J.A., Padoin A.J. \& Giuliani D. 1984: Occurrence of the fly Euxesta sp. on sweet corn at Santa Maria, RS. Ciência Rural 14: 93-99.

Ludwig J.A. \& Reynolds J.F. 1988: Statistical Ecology: A Primer on Methods and Computing. John Wiley, New York, $368 \mathrm{pp}$.

Monteiro-Filho E.L.A. \& Penereiro J.L. 1987: A study on decomposition and succession on animal carcasses in an area of São Paulo, Brazil. Braz. J. Biol. 47: 289-295.

Moura M.O., Monteiro-Filho E.L.A. \& Carvalho C.J.B. 2005: Heterotrophic succession in carrion arthropod assemblages. Braz. Arch. Biol. Techn. 48: 477-486.

NorRIS K.R. 1965: The bionomics of blowflies. Annu. Rev. Entomol. 10: 47-68.

Oliveira-Costa J., Mello-Patiu C.A. \& Lopes S.M. 2001: Muscoid Diptera associated with human corpses at the death scene in the State of Rio de Janeiro, Brazil. Bol. Mus. Nac. N.S. (Zool.) 464: 1-6.

PAYNe J.A. 1972: Insects succession and decomposition of pig carcasses in water. J. Georgia Entomol. Soc. 7: 153-162.

SAS Institute Incorporation 1988: SAS/STAT User's Guide. Release 6.03. Ed. Cary, North Carolina, USA.

SouZA A.M. \& LinHares A.X. 1997: Diptera and Coleoptera of potential forensic importance in Southeastern Brazil: relative abundance and seasonality. Med. Vet. Entomol. 11: 8-12.

Received December 10, 2007; revised and accepted June 4, 2008 